UNIVERSITY OF CALIFORNIA

BIBLIOGRAPHIC GUIDES 



\section{SERIAL MUSIC}

\section{A Classified Bibliography of Writings on Twelve-Tone and Electronic Music}

by ANN PHILLIPS BASART

1961

UNIVERSITY OF CALIFORNIA PRESS BERKELEY AND LOS ANGELES 
Univeraity of California Preas

Berkeley and Los Angelos, Californie

Cambridge Univeralty Prese

London, Englend

D 1981 by The Regente of the University of Californita Library of Congrees Catalog Card Number: 61-7538

Manufactured in the United States of America 
In Memoriam E.S.S. 
